\title{
Regulating private tutoring consumption in Korea: lessons from another
}

\section{failure}

\begin{abstract}
The proliferation of private tutoring is a widespread phenomenon, Korea being one the most notable examples. Indeed, successive Korean governments have attempted to limit private tutoring consumption for more than four decades. In 2006, state education authorities imposed a restriction on operating hours of hagwon (private tutoring academies) in an attempt at reducing the economic and time resources spent on private tutoring. Since then, some provincial authorities have modified the curfew on hagwon. We take advantage of these policy shifts to identify average treatment effects taking a difference-in-differences approach. Our findings suggest that enforcing the curfew did not generate a significant reduction in the hours and resources spent on private tutoring, our results being heterogeneous by school level and socioeconomic status. Demand for private tutoring seems to be especially inelastic for high school students, who increased their consumption of alternative forms of private tutoring. As the consumption of private tutoring is positively correlated with academic performance and socioeconomic status, strengthening the curfew may have a negative effect on the equality of educational opportunities.
\end{abstract}

JEL classification: I21; I22; I24

Keywords: Educational policy; Tutoring; Demand for schooling; Expenditures.

Acknowledgment: The authors gratefully acknowledge financial support by the EDU201342480-R project funded of the Spanish Ministry of Economy and Competitiveness. 


\section{Regulating private tutoring consumption in Korea: lessons from another}

failure

\section{Introduction}

Private tutoring can be defined as a set of activities, supplementary to mainstream schooling, whose aim is to boost academic performance in exchange for monetary payment (Bray, 1999; Bray, 2006). Private tutoring can adopt a variety of forms: one-to-one classes, group classes or even radio or internet-based tuition. The proliferation of private tutoring seems to be a growing phenomenon in several countries across different continents (Bray and Kwo, 2014), its causes being heterogeneous (Dang, 2007; Tansel and Bircan, 2006).

Private tutoring has several beneficial effects, the main one being a student's enhanced academic performance. However, this so-called "shadow education" (Bray, 1999; Bray, 2009) can also have various detrimental effects, not least the high opportunity cost for the students and the heavy financial burden for their families. Private tutoring consumption is positively correlated with household income (OECD, 2014); therefore, if the amount of private tutoring received affect academic achievement - as some studies, including Choi, Calero, and Escardibul (2012), seem to suggest - then concerns are raised about the equity and equality of educational opportunities.

The Republic of Korea (hereinafter, Korea) has one of the largest private tutoring industries in the world. The OECD (2012a:24) reports that the burden of private tutoring on Korean households accounted for $10.7 \%$ of average household income per student in 2010 (making it also a key factor in explaining the country's low fertility rates). According to the 2009 Survey of Private Education Expenditure (SPEE) conducted by the Korean National 
Statistics Office (KOSTAT), $87.4 \%$ of elementary school students, $74.3 \%$ of middle school students and $62.8 \%$ of general high school students received private tutoring in $2009^{1}$, with an average monthly private tutoring expenditure per student of 242 thousand Korean won (approximately 220 US dollars) in 2009. Total expenditure on private tutoring in Korea amounted to 21.626 trillion won, equivalent to $2 \%$ of Korea's GDP. According to this same survey, two thirds of those who receive private tutoring are taking lessons at private academic institutes, called hagwon.

Since the 1970s, Korea has been at the front line of the design of new policies for tackling the proliferation of private tutoring. In 2006, in a new attempt to curb the thriving private tutoring market and to revive public education, the Korean government decided to place a 10 p.m. curfew on the operating hours of hagwon. As a result, household spending on private tutoring has gradually decreased since reaching its highest peak in 2009. The government believes that the fall in private tutoring expenditure is an indication that the reforms have begun to take effect and that the 10 p.m. curfew has played a substantial role in this (Han 2011). However, to conclude that this reduction is attributable to the hagwon curfew may be erroneous as other factors, such as the sluggish real economy, could also have had an impact on the fall in private tutoring expenditure.

The main aim of this paper is to evaluate the impact of the advancement in the implementation this new policy (i.e., the curfew on the academies' operating hours) aimed at regulating private tutoring markets. More specifically, we focus on the effect of enforcing the curfew on private education expenditure and on the time dedicated to private tutoring activities. We estimate mean and heterogeneous effects by educational level and socioeconomic status applying difference-in-differences (DD) estimators to the 2009-2012

\footnotetext{
${ }^{1}$ Bray (2013:414) reports similar information for a set of ten countries where private tutoring is prevalent. The only country where figures were close to Korea's was urban China, where 73,8\%, 65,6\% and 53,5\% of primary, lower secondary school and high school students, respectively, consumed private tutoring.
} 
waves of the SPEE. By doing so, we are able to overcome many of the information problems identified by Bray and Kobakhidze (2014) in previous studies of private tutoring ${ }^{2}$.

The main findings of this study can be summed up as follows: First, enforcing the extension of the curfew did not generate a significant reduction in the hours and resources spent on private tutoring. Second, demand for private tutoring seems to be especially inelastic for high school students, who increased their consumption of alternative forms of private tutoring. This raises equity issues concerning equality of educational opportunities, given the higher cost of these alternative forms of private tutoring. Policy recommendations based on our analysis should be of interest not only for Korean authorities but also for the wide set of countries with an overheated private tutoring market.

The article proceeds as follows: Section 2 provides an overview of the demand for and the impact of private tutoring, and charts the struggle mounted by Korean authorities against this phenomenon, the hagwon curfew being one of their latest attempts. Section 3 describes the empirical methodology and the dataset employed in the analysis. In section 4 we present our main results concerning the impact of strengthening the curfew on expenditure and on the time spent on private tutoring activities. The section concludes with a discussion of these results and their policy implications.

\section{Private tutoring in Korea: demand, impacts and policy evolution}

Korea is one of the most frequently studied cases in the private tutoring literature, due to the magnitude of the business and the seriousness with which successive governments have sought to control it. In this section we present a brief overview of the demand for and the

\footnotetext{
${ }^{2}$ More specifically, Bray and Khobakhidze (2014) focus on the problems of international assessments such as TIMSS and PISA. The cross-sectional nature of data, imprecise questions and broad definitions of "private tutoring" are among the most relevant shortfalls of these databases.
} 
impact of private tutoring (2.1), we summarize the campaign mounted by the Korean authorities against private tutoring (2.2) and, finally, we explain the curfew imposed on the hagwon (2.3).

\subsection{Demand for and impact of private tutoring}

Various factors account for the proliferation of private tutoring in Korea, a country where, as it will be seen, Bourdieu's cultural and social reproduction theory has a high explanatory capacity (Bourdieu, 1973). In this sense, Korean families regard education as one of the main channels for ensuring class reproduction and social promotion. Kim and Lee (2010) claim that parents demand private tutoring as a means of compensating for the poor quality of state schooling, especially because the former provides more individualized attention. This argument is persuasive; yet, it seems insufficient to explain the overheated demand for private tutoring in the country. The fact that Korean public education expenditure as a percentage of GDP is $4.7 \%$, higher that is than the 2009 OECD average of $4.0 \%$, suggests that the relative competitiveness of public education may be low not because of the level of public investment, but because of the country's more consumer-oriented, high quality private tutoring services (OECD, 2012b:4). Alternatively, Bray (2006) claims that low salaries paid to mainstream teachers may likewise yield an increase in demand for private tutoring in some developing countries. However, this is not the case in Korea, where teachers are well-paid in comparison to their counterparts in other OECD countries -only German and Luxembourger high school teachers at the top of the scale are better paid than the Korean (OECD, 2015).

Bray and Kwok (2003), among others, observe that the cultural history of Korea is another critical reason accounting for the demand for private tutoring. Many Asian countries, including Korea, have been highly influenced by Confucianism, a system of teachings in 
which the importance of education is emphasized as a tool for personal development and the primary mechanism promoting mobility (Choi, 2010:24).

Finally, against this cultural backdrop, the sizeable economic and non-economic premiums of graduating from an elite university further shape a scenario in which the country is obsessed with private tutoring (Choi et al., 2012; Chae, Hong, and Lee, 2005). Since 1950, the Korean education system has adopted the following structure: six years of primary school; three years of lower secondary education; three years of upper secondary education; and four years of university studies. There are two types of high school: general high schools, where pupils are educated to go on to university, and vocational high schools. The first nine years of schooling are compulsory and free, while high school education is virtually universal, with only modest tuition fees being charged (Kim, 2004:3). According to the OECD (2011), in 2009, $98 \%$ of 25 to 34-year-old Koreans had successfully finished high school education, while $63 \%$ of these had completed tertiary education: both proportions are the highest among all OECD countries. The percentage of high school graduates who begin four-year university courses or two-year technical college studies was reported to be $83.8 \%$ in 2008, which is also very high compared to other OECD countries (KEDI, 2009:66). However, as the average university degree premium fell, competition for admission to the more prestigious universities became notoriously fiercer. As Lee and Brinton (1996) and Choi et al. (2012) highlight, the benefits of attending an elite university in Korea extend well beyond those of an individual's human capital, as school ties provide additional advantages in the labor market as a crucial source of social capital. Thus, young students face a tremendous amount of competition for the few places offered by the most prestigious universities as parents are willing to adopt any strategy to help their children gain an upper hand over their competitors (Park, Byun, and Kim, 2011). 
College entrance depends primarily on academic achievement at school and on the results of the College Scholastic Achievement Test (CSAT), an objectively graded examination sat once a year. Consequently, most general high school students focus exclusively on test preparation (Byun, Schofer, and Kim, 2012) and Korean families end up spending considerable sums of money on private tutoring to support their children, a practice that is not limited solely to children from higher socio-economic groups, but one that is widespread across the income groups (Lee, Jwa, and Lim, 2014).

The intensity with which private tutoring is consumed has both advantages and disadvantages. The main advantage is that pupils enhance their learning outcomes, a result supported by several studies (see, for example, Dang and Rogers, 2008; Kang, 2007). This enhanced academic achievement may also be beneficial to the economy as a whole, since the accumulation of human capital increases labor productivity, prompting economic growth. Additionally, private tutoring has a positive effect on the labor market: in 2009, this sector became the largest employer of graduates in the humanities and social sciences (OECD, 2014:95).

However, various experts conclude that the proliferation of private tutoring can have a number of harmful impacts. First, in a highly competitive environment, the health of the country's pupils is put a risk. This is especially true of students receiving private tuition late into the night and on weekends (Rhie, Lee, and Chae, 2011). Second, a reliance on private tutoring inevitably has some impact on public education. As students are often already familiar with the material being taught at school (having already studied it privately), the levels of motivation of both students and teachers are negatively affected (Choi et al., 2012). Third, a dependence on private tutoring may impede the development of students' selfdirected learning and problem-solving abilities (Kim, 2010:7). Fourth, private tutoring has an 
opportunity cost which may restrict the development of skills and contents beyond those taught at school.

In addition to these various effects, another serious problem identified by economists is that private tutoring gives rise to an issue of efficiency as well as one of equity. First, private tutoring activities may generate negative externalities, since students are likely to demand more private tutoring services than their optimum level so as to at least maintain their relative positions in the academic performance distribution (Kim, 2010). As a result, private tutoring may be over-consumed, compared to a socially optimum level, despite the fact that the amount of private tutoring consumed by each student is individually optimal. As such, the overheated private tutoring market in Korea can be explained in the framework of the classic prisoner's dilemma which leads to a socially inefficient equilibrium (Choi, 2010). In other words, decisions which are rational at the individual level -consuming private tutoring- can lead to a socially inefficient situation -the country may not be investing in other activities with a higher return.

As regards the equity issue, private tutoring is expensive, which means students from wealthier families are likely to consume more or higher quality services. Indeed, Korean families perceive one-to-one and group tuition - the most expensive types of private tutoring - as being the most effective ${ }^{3}$. All in all, this situation can undermine the equality of educational opportunities. Thus, the Korean government has adopted different measures over recent decades in an attempt to control private tutoring for reasons of both efficiency and equity.

\footnotetext{
${ }^{3}$ Choi (2008), however, is unable to confirm the greater effectiveness of one-to-one tutoring. His results suggest that the effect of private, one-to-one tutoring on college entrance is positive, but statistically insignificant.
} 


\subsection{A testing ground for regulating private tutoring}

In 1969, the government effectively ended selective education at the middle school level by abolishing entrance examinations. The primary aim was to control what was seen as wasteful private tutoring competition among children preparing for entrance exams to the most prestigious middle schools (Chung, 2002). For the same motive, in 1974, the high school equalization policy ${ }^{4}$ was implemented in Seoul and Busan, Korea's two largest cities, and subsequently expanded to several other major cities through to 1980 (Kim and Lee, 2010). However, contrary to government expectations, spending on private tutoring showed no signs of abating. Rather, the equalization policy contributed significantly to raising the demand for individualized education (Kang, 2007), as households turned to private tutoring as a tool to supplement the equalized state education system (Kim and Lee, 2010).

Against this backdrop, in 1980, the Korean government took steps to prohibit all forms of private tutoring. However, parents, willing to hire private tutors at any expense, turned to the black private to meet their demand. At the same time, the suppliers of illegal private services demanded risk premiums, thus increasing further the price. Thus, paradoxically, the regulation of private tutoring seems to have exacerbated the inequality of educational opportunities by polarizing the consumption of the sector's services.

The democratization and liberalization of Korea saw the outright ban on private tutoring relaxed somewhat. However, until the Constitutional Court ruled that the prohibition on private tutoring was indeed unconstitutional in 2000 , the government had only permitted two types of operator: college students and the hagwon. In the latter case, the government imposed strict restrictions in the form of specific requirements regarding the qualifications of

\footnotetext{
${ }^{4}$ The high school equalization policy introduced a lottery system whereby students were randomly allocated to the public and private schools within a province. As a result, the schools became more homogeneous as they could no longer select students and curricula, teacher salaries and tuition fees were regulated by the government.
} 
the instructors, the schools facilities, and fees (Kang 2007). Despite this, the number of hagwon increased dramatically from 381 in 1980 to 14,043 in 2000 , while the number of students enrolled at hagwon increased in the same period from 118,000 to $1,388,000$ (Kim and Lee, 2010). According to National Tax Service data, there were nearly 105,000 hagwon operating in Korea by 2013, up from 92,433 in 2008 (Korean Economic Daily, 2015).

At the same time, the government has sought to strengthen public education in the belief that the gap between the quality of mainstream education and private tutoring accounts for the willingness of households to hire private tutoring services. Thus, the government has increased inputs to public education substantially in an effort to improve school facilities, the student-teacher ratio, and the quality of school teachers. However, despite the marked increase in government spending, household spending on private tutoring has continued to rise at a remarkable pace (Kim and Lee, 2010).

Since the first decade of the new century, the government has been actively involved in providing low-cost substitutes for private tutoring so that demand for the latter could be absorbed into the public system. These reforms include the Educational Broadcasting System (EBS) lectures that specifically focus on preparing the CSAT, and "after-school" programs, introduced in 2006, that offer hagwon-like lessons in schools. ${ }^{5}$ These measures, however, did little to cool the demand for private tutoring. As links between the EBS lectures and the CSAT intensified (with many CSAT questions being drawn from the EBS lectures), hagwon that specifically focused on the EBS lectures became very popular. The "after-school" programs enjoyed some success, especially as they provided low-income pupils with additional education opportunities. However, students from wealthier backgrounds continued to consume private tutoring services. Indeed, some were found to attend both the "after-

\footnotetext{
${ }^{5}$ These are extra lessons offered by the schools for which students pay a small tuition fee, the government meeting the extra-funding needed. Initially, schools were forbidden from signing contracts with private institutions to provide these after-school programs.
} 
school" programs and to receive private tutorials. According to the 2009-2012 SPEE data, $49.8 \%$ of middle and high school students whose monthly household income was more than 4 million Korean won both received private tutoring and attended the "after-school" programs, while $27.7 \%$ of them only enrolled for private tutoring. In the case of households with a monthly income equal to or below the 4 million won threshold, these figures were 37.5 and $18.1 \%$, respectively.

In addition, the government has reformed the university entrance system several times, seeking to reduce the importance attached to the CSAT and by introducing elements to the admissions system that cannot be acquired by simple memorization. Thus, greater importance is now attached to other selection criteria, including high school records, essay-style exams, extra-curricular activities, involvement in social services, while socio-economic disadvantages are also taken into account. However, these reforms have also failed to be effective and have actually ushered in new forms of private tutoring that specialize in the enhancement of the new selection criteria (Choi et al., 2012).

\subsection{The 10 p.m. curfew on operating hours of hagwon}

As the measures aimed at curbing the demand for private tutoring proved ineffective, in 2006 the government introduced a new measure, namely, the regulation ${ }^{6}$ of the operating hours of hagwon. Before 2006, closing hours in some regions were already controlled by local ordinances; however, these curfews had no real authority in law (Kang, 2010). In September 2006, the reform of the "Act on the establishment and operation of private teaching institutes and extracurricular lessons" strengthened the powers of each of the

\footnotetext{
${ }^{6}$ Bray and Kwo (2014) review different types of regulation from a comparative perspective.
} 
municipal and provincial education offices with regards their regulatory authority over the hagwon. By 2009, all the offices had imposed a curfew on the operating hours of hagwon.

In April 2009, Seungjoon Kwak, chairman of the Presidential Council on Future and Vision first raised the possibility of fixing the same 10 p.m. curfew for all hagwon. He argued that this restriction would help households cut their expenditure on private tutoring and safeguard the health of their children. However, the plan faced strong opposition from a group of hagwon owners and parents, who claimed that the policy would result in many students going to the hagwon in the early morning and on weekends, especially as many high schools were keeping pupils at schools until 10 or even 11 p.m. (Kang, 2009). Others argued that while the policy might reduce the time students spent on private tutoring activities in the hagwon, the demand for private tutoring services would simply be substituted by private tutors. In this case, the curfew would simply widen the gap between high- and low-income earners, given that the former would be able to hire the best private tutors (Bae, 2009). Indeed, a group of hagwon operators in Seoul and Busan, with the support of both parents and students petitioned the Constitutional Court, claiming that the curfew violated children's educational rights. Despite the opposition, the curfew was declared constitutional by the court in October 2009, and the nationwide implementation of the 10 p.m. closure gained momentum. That same month, the Ministry of Education, Science, and Technology reported that the government was expected to urge the amendment of the ordinances of the education offices in all cities and provinces and to fix a 10 p.m. curfew. At the same time, the government cracked down on those hagwon that violated the curfew, even offering financial rewards to citizens who reported offenders. Daegu, Gwangju, and Gyeonggi revised their ordinances accordingly in 2011, while the rest of the regions have been pushing ahead with the reform. As a result, a total of 13 education offices have completed or partly completed the revision of their ordinances regulating the operating hours of hagwon to 10 p.m. (KEDI, 
2012:15-16). Table 1 provides a summary, by educational level and Korean province, of recent changes in the closing times of hagwon. As can be seen, during the period 2009 to 2012 period, the provinces have either maintained or tightened the curfew.

Table 1. Curfew imposed on hagwon (closing times), 2009-2012

\begin{tabular}{|c|c|c|c|c|c|}
\hline & & & ddle s & dents & \\
\hline & Region & 2009 & 2010 & 2011 & 2012 \\
\hline & Daegu & 12 & 12 & 10 & 10 \\
\hline & Jeonnam & 12 & 12 & 10 & 10 \\
\hline Treatment group & Incheon & 12 & 12 & 12 & 10 \\
\hline & Gyeonggi & 11 & 11 & 10 & 10 \\
\hline & Jeju & 12 & 12 & 12 & 11 \\
\hline & Seoul & 10 & 10 & 10 & 10 \\
\hline & Busan & 10 & 10 & 10 & 10 \\
\hline Control group & Gwangju & 10 & 10 & 10 & 10 \\
\hline & Chungbuk & 11 & 11 & 11 & 11 \\
\hline & Gyeongbuk & 11 & 11 & 11 & 11 \\
\hline & Ulsan & 12 & 12 & 12 & 12 \\
\hline & Gyeongnam & 12 & 12 & 12 & 12 \\
\hline & & & gh scl & ents ( $p$ & \\
\hline & Region & 2009 & 2010 & 2011 & 2012 \\
\hline & Daegu & 12 & 12 & 10 & 10 \\
\hline Treatment group & Gwangju & 12 & 12 & 10 & 10 \\
\hline & Gyeonggi & 12 & 12 & 10 & 10 \\
\hline & Incheon & 12 & 12 & 12 & 11 \\
\hline & Seoul & 10 & 10 & 10 & 10 \\
\hline & Busan & 11 & 11 & 11 & 11 \\
\hline & Ulsan & 12 & 12 & 12 & 12 \\
\hline Control group & Chungbuk & 12 & 12 & 12 & 12 \\
\hline & Jeonnam & 12 & 12 & $12^{\mathrm{a}}$ & $12^{\mathrm{a}}$ \\
\hline & Gyeongbuk & 12 & 12 & 12 & 12 \\
\hline & Gyeongnam & 12 & 12 & 12 & 12 \\
\hline & Jeju & 12 & 12 & 12 & 12 \\
\hline
\end{tabular}

SOURCE: Ordinance regarding the establishment and operation of private teaching institutes and extracurricular lessons specified on the website of each city and provincial education office.

${ }^{a}$ The exact curfew for Jeonnam is 11:50 p.m.

However, there is little evidence of the effectiveness of the curfews in achieving their objectives (i.e., reducing expenditure and the time spent on private tutoring activities). While there are a number of papers which have analyzed previous policies -for example, Lee et al. (2010) or Byun (2010)-, to the best of our knowledge, only Kim (2009), Kim and Chang 
(2010), and Choi and Cho (2015) have attempted to evaluate the effectiveness of this regulation. Kim (2009) and Kim and Chang (2010) applied Tobit models to two different databases, and found a small negative impact of time regulations on monthly expenditure and weekly hours spent on private tutoring. Kim (2009) did not find any evidence that the regulation significantly increased monthly spending on other types of private tutoring. Both studies specifically analyzed the effect of regulating the operating hours of hagwon on household spending on private tutoring for general high school students before the enactment of the 10 p.m. curfew. Unlike Kim (2009) and Kim and Chang (2010), the present paper, using the more robust methodological framework of difference-in-differences, measures the actual impact of the implementation of the 10 p.m. curfew on private tutoring expenditure by focusing on changes in the curfews that have been made since 2009 . We also analyze heterogeneous effects by socioeconomic and educational level, namely, middle school and general high school.

Choi and Cho (2105) used a difference-in-difference framework for analyzing the impact of the curfew on spending and time spent in private tutoring. They focused on mean effects for high school students. While studying mean results is useful for describing general trends, it is insufficient for understanding the mechanisms driving the (in)effectiveness of a complex policy such as the curfew. Additionally, as it will be explained in section 3, their use of a linear model for treating censored data may be misleading.

While the expected impact of the curfew on expenditure and time spent on hagwon is trivial (a reduction in both), the overall effect of the measure on expenditure and time spent on private tutoring in general remains unclear. As alternative forms of private tutoring - most specifically, one-to-one and group tuition - are more expensive, the overall effect of the policy will depend on the prevalence of substitution or income effect. If admission to the top universities is the main objective driving the demand for private tutoring services, we would 
expect the substitution effect to prevail - i.e., families showing a greater willingness to hire additional forms of private tutoring as the date for sitting the CSAT approaches.

\section{Methodology and data}

\subsection{Methodological approach: Difference-in-Differences (DD) estimation}

The intuition behind the difference-in-differences (DD) method is that to investigate the effect of a specific intervention ("treatment"), the difference in outcomes after and before the intervention for groups affected by that intervention ("treatment groups") are compared with the same difference for unaffected groups ("control groups") (Bertrand, Duflo, and Mullainathan, 2004:249). Applied to the issue at stake, the DD approach compares shifts in private tutoring expenditure for students in regions that have changed their curfew on hagwon, to those in regions that have maintained their initial curfew.

Given that the curfew policy is not completely exogenous, i.e., some unobserved regionallevel characteristics may affect both the regulation of the operating hours of the hagwon and private tutoring expenditure (our two dependent variables), the error term might be correlated with the independent variable. Parents' zeal for children's education can be taken as an example of such unobserved regional-level characteristics. Parents in some regions might be more eager to invest in their children's education -for example, Kang et al. (2007) suggest the equalization policy ${ }^{7}$ might have led some families to move to larger cities. Basically, their level of enthusiasm for children's education is unobservable, but is likely to have an impact on local education offices' decision on regulating of the operating hours of hagwon as well as

\footnotetext{
${ }^{7}$ The so-called equalization policy, applied in Korea since the 1970 decade, consists in the assignment of students to schools based strictly on their neighbourhood of residence.
} 
average private tutoring expenditure in those regions. Being concerned about the soaring private tutoring expenditure, they may support the policy of strengthening the hagwon curfew or it may be the opposite case if they want their willingness to make an investment in children's education to be unconstrained from the hagwon curfew.

The presence of the endogeneity problem thus leads an OLS estimator to be biased. If the average treatment effect of the regulation of the operating hours of the hagwon on private tutoring expenditure is measured by comparing average private tutoring expenditures across regions applying a simple OLS estimator to cross-section data, the estimate will be biased as other unobservable characteristics such as parents' zeal for children's education affecting both the regulation of the operating hours of the hagwon and private tutoring expenditure may differ by region. On the other hand, if the research question is analyzed by comparing average private tutoring expenditure of the same region before and after the policy change, it will also produce bias since other characteristics affecting private tutoring expenditure may have changed over time as well. In both cases, the OLS estimator is biased, and thus does not measure a causal effect, but only a correlation.

Under certain assumptions, the DD method allows us to at least control for the unobserved regional-level characteristics that are fixed over time, thus removing a potentially large source of omitted variable bias (Angrist and Pischke, 2009). DD estimations control for timeinvariant regional-level characteristics by comparing private tutoring expenditure costs and the time spent on private tutoring activities within regions over time and shared time trends by comparing differences across regions. Therefore, the use of the DD estimation enables us to measure the unbiased treatment effect of the regulation of the operating hours of hagwon.

As discussed above, by 2009 all provincial education offices around the country had fixed their own curfew on the hagwon; however, some of them changed this restriction in 2011 and 2012. This variation of hagwon curfew policy across regions makes it appropriate to exploit a 
DD estimator to investigate the effect of the regulation on private tutoring expenditure. The treated group comprises those regions that modified their curfew between 2009 and 2012 . Thus, the treatment considered in this study is not exactly the imposition of the 10 p.m. curfew, but rather the further strengthening of existing curfews (Table 1). The fact that the curfew time even differs within a region by school level, led us to split the analysis between middle and general high school students, the main consumers of private tutoring in Korea. Control groups are identified, for each educational level, as those regions in which the hagwon closing times remained constant during the period.

Table 1 provides a summary of the curfews fixed by each education office. Based on the previous discussion, seven treatment groups are identified for middle school students and four for high school students. In 2011, the Jeonnam education office changed its curfew from midnight to 11:50 p.m. for high school students. However, a ten-minute difference is not expected to have a significant effect on private tutoring expenditure, so Jeonnam is categorized as a control group for high school students.

The timing of the implementation of the reforms posed an additional challenge for the identification of the treatment. As described in subsection 3.2 below, the data used in this analysis were drawn from a survey completed by parents twice a year. The problem is that some regional reforms were implemented during one of these reference periods: the first being from March to May and the second from July to September. For example, in the cases of Gangwon, which introduced a change on 30 March 2012, and Daejeon, which imposed an initial curfew on 10 April 2009, including these regions in the analysis might have influenced the results and so they were dropped from the analysis. As a result, we are left with five treatment groups for middle school students (Daegu, Jeonnam, Incheon, Gyeonggi, and Jeju) and four treatment groups for high school students (Daegu, Gwangju, Gyeonggi, and 
Incheon). It should also be borne in mind that the enforcement of the curfews also differs across regions and school levels ${ }^{8}$.

However, the credibility of this approach relies on a set of assumptions. First, the parallel trend assumption needs to hold in order for a DD estimator to yield a consistent estimate of the treatment effect; that is, in the absence of the treatment, private tutoring expenditure trends would have been the same in both treatment and control groups. This is analyzed graphically (Figure 1). Results seem to confirm this assumption for high school students (Figure $1 \mathrm{~B}$ and $\mathrm{D}$ ): the average weekly hours and yearly expenditure dedicated to private tutoring in the treatment and control groups followed a parallel evolution between 2009 and 2010 (prior to the enforcement of the hagwon curfew). This assumption does not seem to hold as strongly for middle school students (Figure 1 A and C). Thus, the results for middle school students have to be interpreted with caution and our analysis focuses primarily on the findings for high school students.

\footnotetext{
${ }^{8} \mathrm{We}$ also performed the analysis splitting the treatment group into two (one hour reduction and two hour reduction), as the magnitude of the changes in the curfew was different. Main results remained basically unaltered and are available upon request.
} 
Figure 1. Parallel trend assumption
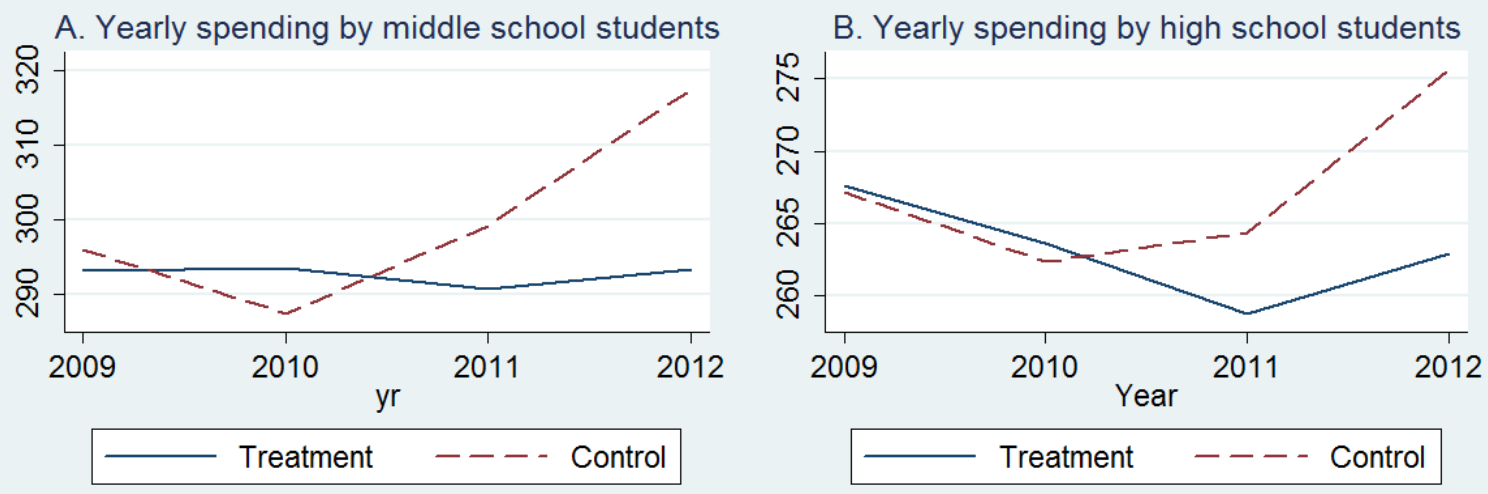

C. Weekly hours by middle school students

D. Weekly hours by high school students
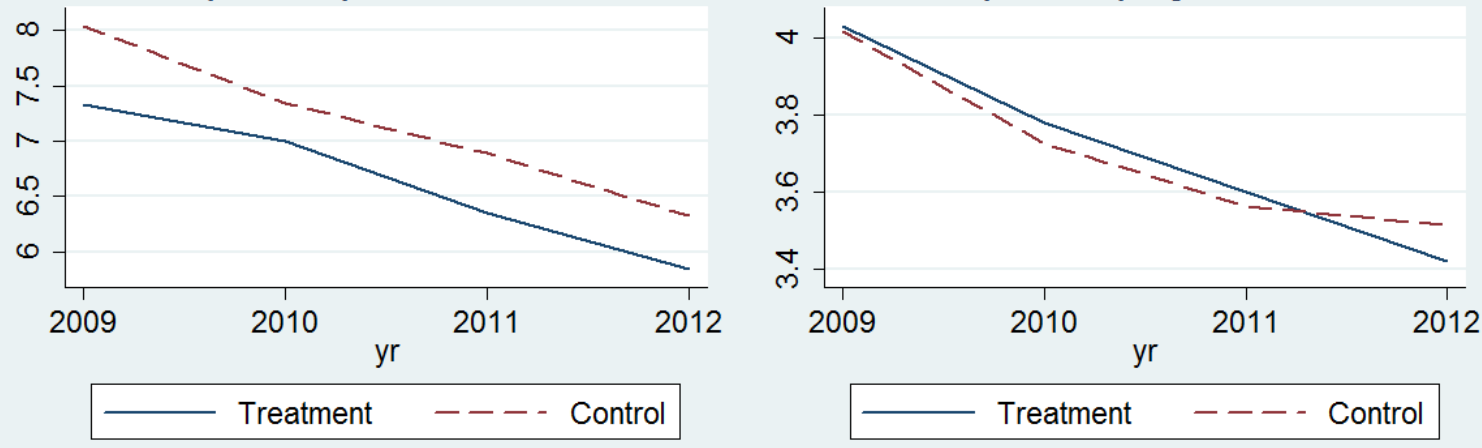

NOTE: All the variables regarding private tutoring expenditure are presented in 10 thousands of Korean won.

A second issue is that the DD estimator is inconsistent if an 'Ashenfelter dip' occurs. The Ashenfelter dip indicates that treated individuals might have suffered bad outcomes immediately prior to treatment assignment due either to the selection of individuals or an anticipation of their participation in the treatment. However, here, anticipation of the implementation of the curfew did not result in parents increasing their private tutoring expenditure immediately prior to the imposition of the stricter curfew.

Finally, the DD estimates would be biased if the composition of the treatment and control groups changed as a result of the treatment. This would only be a problem here if households moved between regions in search of less strict curfews on the operating hours of hagwon in order to consume more private tutoring services. However, there is no evidence of Korean families having increased their geographical mobility after 2009. Indeed, our results seem to 
indicate that families adopted other strategies for countering the effects of the enforcement of the curfew.

Given the existence of multiple groups and time periods, we opted to employ the general framework suggested by Bertrand et al. (2004) in which DD estimates and their standard errors derive from using OLS in repeated cross-sections of data on individuals -in our case, students- in both treatment and control groups for several years before and after a specific intervention. The equation at the individual level is

$$
Y_{i r t}=\alpha_{r}+\delta_{t}+\gamma \cdot X_{i r t}+\beta \cdot I_{r t}+\varepsilon_{i r t}
$$

where $Y_{i r t}$ is the outcome of interest for individual $\mathrm{i}$ in region $\mathrm{r}$ in year $\mathrm{t}$ (private tutoring expenditure -in log terms- or hours devoted to private tutoring); $\alpha_{r}$ is a full set of region dummies; $\delta_{t}$ is a full set of year dummies; $X_{\text {irt }}$ is individual-specific covariates (gender, dummies for household income, dummies for parents' educational attainment, dummies for parents' age, dummies for parents' economic activity participation, and dummies for size of the region); $I_{r t}$ is an indicator as to whether the curfew is further strengthened in region $\mathrm{r}$ in year $\mathrm{t}$; and $\varepsilon_{i r t}$ is an error term. The region fixed effects $\alpha_{r}$ capture any time-invariant difference in outcomes between the treatment and control groups, while the year fixed effects $\delta_{t}$ capture how both groups are affected over time by any non-treatment forces (Slaughter, 2001:210). Our dependent variables take a zero value for a large number of households ${ }^{9}$. Following Tansel and Bircan (2006), we obtain consistent estimates using a tobit framework which controls for the censored nature of the data -the use of OLS, which assumes normally distributed data, would hence be inappropriate. Following the argument of

\footnotetext{
${ }^{9}$ In our sample, $41.3 \%$ of the middle and high school students do not take any kind of private tutoring. For oneto-one private tutoring and hagwon private tutoring, those figures are $85.4 \%$ and $57.9 \%$, respectively.
} 
Bertrand et al. (2004), we compute robust standard errors to prevent overestimation of tstatistics and significance levels. The DD estimator $\beta$ can be interpreted as the effect of the enforcement of a curfew on operating hours of hagwon on private tutoring expenditure/ hours spent on private tutoring activities.

Since curfews differ across school levels, the sample is divided into two subsamples: middle school and general high school students. The same estimation model is applied to both subsamples. Vocational high school students are excluded from the sample, as their academic profile and private tutoring consumption patterns differ significantly from students following the academic path $^{10}$. Primary school students are excluded from the analysis too, as the consumption of private tutoring is mainly concentrated at higher educational levels.

Additionally, in the last part of our analysis, we split the high school sample into two (high- and low-income households) to check for the existence of heterogeneous effects of the enforcement of the curfew on the time and money spent on different types of tutoring. This exercise allows us to provide a clear picture of the redistributive effects of enforcing the curfew.

\subsection{Data}

This paper employs the Survey on Private Education Expenditure (SPEE) conducted since 2007 by the Korean National Statistics Office (KOSTAT). It provides detailed information on the consumption of private education services by Korean students (time spent, expenditure, type of tutoring). The survey is answered twice a year (June and October) by 46,000 parents of students attending 1,081 elementary, middle, and high schools across the country.

\footnotetext{
${ }^{10}$ Choi et al. (2012) discuss the different profile of vocational high school students.
} 
Students at each school level are selected by a stratification procedure designed to be representative of the national population at that school level. More specifically, after stratifying schools into four levels (elementary, middle, general and vocational high school) and 16 cities and provinces, the schools are independently sampled by grades. For elementary school, grades are stratified into 1 3 grades and 4 6 grades, and then three classes are randomly chosen per school. For middle and high schools, one class is sampled per school (KOSTAT 2011).

We use data from 2009 to 2012. The rationale behind this choice is that, since 2009, KOSTAT provides information by administrative district -that is, by provinces and large cities-, which constitutes crucial information for performing the DD estimation, as each province and large city has its own education office and hagwon operating hours differ from one office to another. Thus, the availability of information for each province/ city facilitates the analysis of the impact of changes in the hagwon curfew on private tutoring expenses.

Several regions that implemented amendments to the ordinance during the reference periods of the survey are excluded from the sample. They include Daejeon and Jeonbuk, which enacted their initial curfews during the 2009 reference periods, and Gangwon and Chungnam, which changed their curfews during the 2012 reference periods. As a result, we work with a sample of 190,276 middle and general high school students ${ }^{11}$, from an overall sample of 349,365 students.

The dataset provides detailed information about the number of hours dedicated to private tutoring and the corresponding expenditure on these services. Private tutoring expenditure is reported for each subject (Korean, English, math, and science) and for each tutoring type (i.e., one-to-one tuition, group tuition, hagwon lessons, use of textbook combined with visit from a

\footnotetext{
${ }^{11}$ A student who reported that her average weekly hours spent on private tutoring for academic purpose was 80 hours was dropped from the analysis as it is clearly an abnormal value.
} 
tutor, and paid internet and correspondence lecture tuition). All the variables concerning expenditure are expressed in real terms, adjusted to 2010 prices using a consumer price index.

The dataset contains information on student characteristics (gender and academic performance in class), household characteristics (monthly household income, parents' education level, age, and economic activity participation), and the size of the region in which the household resides. These variables, except for academic performance in class (due to the potential problem of endogeneity ${ }^{12}$ ), are included in the regression model as individualspecific covariates. Treatment variables are identified as follows. A regulation dummy is assigned a value of one for regions and time periods subject to the policy strengthening the initial curfew on hagwon. Since the identification of treatment groups differs according to school level, these regulation dummies are created for each school level. Tables A1 and A2 in the Appendix summarize the definitions and the main descriptive statistics, respectively, of the variables used in the empirical analysis.

Table A2 presents the mean values of the main variables in each sample. The first column shows the overall mean for all students, while columns two and three report the means for middle and general high school students. The fourth and fifth columns compare student characteristics according to whether they receive private tutoring or not. Compared to high school students, middle school students spend more time and more money on private tutoring. Moreover, their consumption of private tutoring seems to be heavily concentrated on hagwon tutoring, while high school students also spend a significant amount of money on private, one-to-one tuition (with high school students spending almost twice as much as middle school students).

While classes at the hagwon are the most popular form of private tutoring, the use of textbook and internet and correspondence lectures are the least frequently used methods.

\footnotetext{
${ }^{12}$ Nevertheless, main results remained unchanged when introducing previous performance in the analysis.
} 
SPEE data show a positive correlation between household income and time spent on one-toone tuition, suggesting that this method is considered the most effective for improving pupils' academic performance. However, to the best of our knowledge, no analyses of the heterogeneous effects of tuition methods on academic achievement have yet been performed.

More interestingly, there are systematic differences in student characteristics depending on whether or not they receive private tutoring. In general, those receiving private tutoring are likely to be female, high academic achievers, and from high socio-economic backgrounds (Table A2). The positive correlation between students' achievement and the consumption of private tutoring indicates that the primary objective of such tuition in Korea is not to complement deficient academic achievement, but rather it constitutes a strategy for high academic performers to maintain and strengthen their competitive advantage. This finding is in line with previous studies, see for example, Kim (2007) and Kim (2009).

In the case of students' socio-economic backgrounds, the fourth and fifth columns of Table A2 indicate that the proportion of students whose parents have at least a university degree and the proportion of students whose monthly household income is more than 4 million won are substantially higher among students that receive private tutoring than those who do not. These figures imply that households with high socio-economic status may tend to provide their children with additional educational opportunities in the form of private tutoring.

\section{Results and discussion}

We present the average treatment effects of regulating the operating hours of hagwon on the time devoted to private tutoring (Subsection 4.1) and on expenditure dedicated to these activities (4.2). The article concludes with a discussion of the study's main findings (4.3). 
4.1. The impact of the enforcement of the hagwon curfew on the time dedicated to private tutoring activities

Table 2 presents the average treatment effect of the regulation of the operating hours of hagwon on the number of hours dedicated to all kinds of private tutoring activities. The nonsignificant coefficients clearly show that the extension of the curfew failed to reduce the time spent on private tutoring activities both for middle and high school students. There are two potential explanations for this finding: first that the policy failed to cut the time dedicated to classes offered by hagwon. This being the case, it could simply be concluded that the policy was ineffective. Second, the policy might have succeeded in reducing the amount of time spent on hagwon classes, but that this reduction was completely or partly offset by an increase in the consumption of other types of private tutoring. Although the SPEE does not provide details regarding the amount of time spent on each type of private tutoring activity, the results in subsection 4.2 seem to support this second scenario. 
Table 2. Effects of the enforcement of the curfew on hours spent on private tutoring

\begin{tabular}{|c|c|c|}
\hline VARIABLES & Middle school & High school \\
\hline \multirow[t]{2}{*}{ Regulation } & 0.011 & -0.081 \\
\hline & $(0.126)$ & $(0.101)$ \\
\hline \multirow[t]{2}{*}{ Female } & $-0.353 * * *$ & $0.336 * * *$ \\
\hline & $(0.065)$ & $(0.049)$ \\
\hline \multicolumn{3}{|l|}{ Father's education } \\
\hline \multirow[t]{2}{*}{ High school } & $1.988 * * *$ & $0.813 * * *$ \\
\hline & $(0.235)$ & $(0.154)$ \\
\hline \multirow[t]{2}{*}{ Undergraduate } & $2.930 * * *$ & $1.878 * * *$ \\
\hline & $(0.242)$ & $(0.160)$ \\
\hline \multirow[t]{2}{*}{ Graduate school } & $2.823 * * *$ & $2.085^{* * *}$ \\
\hline & $(0.267)$ & $(0.179)$ \\
\hline \multicolumn{3}{|l|}{ Mother's education } \\
\hline \multirow[t]{2}{*}{ High school } & $0.938 * * *$ & $0.697 * * *$ \\
\hline & $(0.228)$ & $(0.146)$ \\
\hline \multirow[t]{2}{*}{ Undergraduate } & $1.182 * * *$ & $1.254 * * *$ \\
\hline & $(0.239)$ & $(0.155)$ \\
\hline \multirow{2}{*}{ Graduate school } & $1.300 * * *$ & $1.612 * * *$ \\
\hline & $(0.296)$ & $(0.201)$ \\
\hline \multicolumn{3}{|l|}{ Household income } \\
\hline \multirow[t]{2}{*}{ 1 2 million won } & $2.059 * * *$ & $1.443 * * *$ \\
\hline & $(0.264)$ & $(0.217)$ \\
\hline \multirow[t]{2}{*}{$2 \sim 3$ million won } & $5.016 * * *$ & $3.368 * * *$ \\
\hline & $(0.257)$ & $(0.211)$ \\
\hline \multirow[t]{2}{*}{$3 \sim 4$ million won } & $6.750 * * *$ & $4.780 * * *$ \\
\hline & $(0.256)$ & $(0.211)$ \\
\hline \multirow[t]{2}{*}{$4 \sim 5$ million won } & $7.451 * * *$ & $5.516^{* * *}$ \\
\hline & $(0.260)$ & $(0.213)$ \\
\hline \multirow[t]{2}{*}{$5 \sim 6$ million won } & $7.989 * * *$ & $6.250 * * *$ \\
\hline & $(0.265)$ & $(0.218)$ \\
\hline \multirow[t]{2}{*}{ 6 7 million won } & $8.569 * * *$ & $6.795 * * *$ \\
\hline & $(0.279)$ & $(0.227)$ \\
\hline More than 7 million won & $8.810 * * *$ & $7.059 * * *$ \\
\hline & $(0.268)$ & $(0.219)$ \\
\hline Father's age & & \\
\hline $40 \mathrm{~s}$ & $0.628 * * *$ & $0.694 *$ \\
\hline & $(0.189)$ & $(0.402)$ \\
\hline $50 \mathrm{~s}$ & 0.249 & 0.262 \\
\hline & $(0.216)$ & $(0.405)$ \\
\hline Mother's age & & \\
\hline $40 \mathrm{~s}$ & $-0.257 * * *$ & $0.503 * * *$ \\
\hline & $(0.097)$ & $(0.148)$ \\
\hline $50 \mathrm{~s}$ & -0.150 & $0.753 * * *$ \\
\hline & $(0.202)$ & $(0.173)$ \\
\hline Economic activity particip & & \\
\hline Mother only & $-1.831 * * *$ & $-1.307 * * *$ \\
\hline & $(0.181)$ & $(0.138)$ \\
\hline Both & $-0.339 * * *$ & $-0.709 * * *$ \\
\hline & $(0.068)$ & $(0.0518)$ \\
\hline None & $-4.909 * * *$ & $-2.399 * * *$ \\
\hline & $(0.358)$ & $(0.303)$ \\
\hline Size of region & & \\
\hline Metropolitan city & $0.782 * *$ & $-4.538 * * *$ \\
\hline & $(0.354)$ & $(0.333)$ \\
\hline Small city & $1.736 * * *$ & $-3.211 * * *$ \\
\hline & $(0.195)$ & $(0.136)$ \\
\hline Rural area & 0.289 & $-5.710 * * *$ \\
\hline & $(0.213)$ & $(0.163)$ \\
\hline Year FE & Yes & Yes \\
\hline Region FE & Yes & Yes \\
\hline Observations & 70,176 & 107,409 \\
\hline
\end{tabular}

NOTE: $*$ significant at $10 \%, * *$ significant at $5 \%, * * *$ significant at $1 \%$. 
The coefficients of the control variables are consistent with results reported in most previous studies. Students from higher income households and whose parents record a higher educational attainment tend to invest more time in private tuition. It has also been shown that students in households where the father is the sole breadwinner (category of reference for the economic activity participation variable) spend more time on private tutoring than their counterparts do. This may be attributed to the fact that the fathers in such households tend to have well-paid job ${ }^{13}$ and stay-at-home mothers can spend more time and energy on taking care of the educational activities of their children. These results suggest that educational expectations of parents vary according to their level of education and the importance of budgetary constraints on their being able to participate in private tutoring activities. This should be borne in mind when analyzing the next set of results (4.2).

4.2. The impact of the enforcement of the hagwon curfew on spending on private tutoring activities

Table 3 presents the average treatment effect of the enforcement of the hagwon curfew on total private tutoring expenditure (first and fourth columns). We also calculate the impact of strengthening the curfew on private, one-to-one and group tuition expenditure and on hagwon tutoring expenditure separately, in order to identify the existence of a substitution effect. The main finding reported in Table 3 is that the extension of the curfew did not significantly reduce total expenditure on private tuition. As expected, the enforcement of the curfew was successful in decreasing expenditure on hagwon tutoring for both middle and high school students. This reduction in spending was greater for high school students, suggesting that the

\footnotetext{
${ }^{13}$ According to the SPEE from 2009 to 2012, the average monthly household income is slightly higher for double-income families, but the average monthly household income per earner is much higher for single-income families with the father as the only breadwinner. This implies that some of the fathers in such households have a well-paid job, enough not to need an extra income earner in their households.
} 
policy has had a greater impact on high school students, who are more likely to stay late at school. 
Table 3. Effects of the enforcement of the curfew on private tutoring expenditure

\begin{tabular}{|c|c|c|c|c|c|c|}
\hline \multirow[b]{2}{*}{ VARIABLES } & \multicolumn{3}{|c|}{ Middle school } & \multicolumn{3}{|l|}{ High school } \\
\hline & Expenditure & 1:1/Group & Hagwon & Expenditure & 1:1/Group & Hagwon \\
\hline \multirow{2}{*}{ Regulation } & -0.037 & 0.002 & $-0.127 *$ & -0.083 & 0.177 & $-0.197 * *$ \\
\hline & $(0.053)$ & $(0.151)$ & $(0.073)$ & $(0.065)$ & $(0.129)$ & $(0.095)$ \\
\hline \multirow[t]{2}{*}{ Female } & -0.025 & $0.190 * *$ & $-0.170 * * *$ & $0.462 * * *$ & $1.023 * * *$ & $0.157 * * *$ \\
\hline & $(0.027)$ & $(0.078)$ & $(0.037)$ & $(0.032)$ & $(0.063)$ & $(0.046)$ \\
\hline \multicolumn{7}{|l|}{ Father's education } \\
\hline \multirow[t]{2}{*}{ High school } & $1.022 * * *$ & $2.009 * * *$ & $0.953 * * *$ & $0.593 * * *$ & $0.986 * * *$ & $0.594 * * *$ \\
\hline & $(0.101)$ & $(0.305)$ & $(0.131)$ & $(0.103)$ & $(0.206)$ & $(0.149)$ \\
\hline \multirow[t]{2}{*}{ Undergraduate } & $1.578 * * *$ & $2.972 * * *$ & $1.561 * * *$ & $1.366^{* * *}$ & $1.807 * * *$ & $1.443 * * *$ \\
\hline & $(0.104)$ & $(0.313)$ & $(0.135)$ & $(0.107)$ & $(0.213)$ & $(0.154)$ \\
\hline \multirow[t]{2}{*}{ Graduate school } & $1.587 * * *$ & $3.198 * * *$ & $1.670 * * *$ & $1.563 * * *$ & $2.051 * * *$ & $1.746 * * *$ \\
\hline & $(0.113)$ & $(0.339)$ & $(0.150)$ & $(0.118)$ & $(0.236)$ & $(0.171)$ \\
\hline \multicolumn{7}{|l|}{ Mother's education } \\
\hline \multirow[t]{2}{*}{ High school } & $0.390 * * *$ & 0.415 & $0.428 * * *$ & $0.488 * * *$ & $0.763 * * *$ & $0.363 * * *$ \\
\hline & $(0.098)$ & $(0.290)$ & $(0.129)$ & $(0.098)$ & $(0.195)$ & $(0.140)$ \\
\hline \multirow[t]{2}{*}{ Undergraduate } & $0.640 * * *$ & $1.514 * * *$ & $0.540 * * *$ & $0.929 * * *$ & $1.545 * * *$ & $0.864 * * *$ \\
\hline & $(0.102)$ & $(0.302)$ & $(0.135)$ & $(0.104)$ & $(0.207)$ & $(0.149)$ \\
\hline \multirow[t]{2}{*}{ Graduate school } & $0.803 * * *$ & $1.822 * * *$ & $0.663 * * *$ & $1.199 * * *$ & $2.145 * * *$ & $0.806 * * *$ \\
\hline & $(0.122)$ & $(0.367)$ & $(0.169)$ & $(0.129)$ & $(0.257)$ & $(0.192)$ \\
\hline \multicolumn{7}{|l|}{ Household income } \\
\hline \multirow[t]{2}{*}{ 1 2 million won } & $0.846 * * *$ & $0.853 * *$ & $1.033 * * *$ & $1.042 * * *$ & $1.313 * * *$ & $1.227 * * *$ \\
\hline & $(0.117)$ & $(0.349)$ & $(0.153)$ & $(0.144)$ & $(0.306)$ & $(0.209)$ \\
\hline 2 3 million won & $2.228 * * *$ & $2.844 * * *$ & $2.520 * * *$ & $2.416 * * *$ & $3.197 * * *$ & $2.597 * * *$ \\
\hline & $(0.113)$ & $(0.336)$ & $(0.148)$ & $(0.140)$ & $(0.296)$ & $(0.203)$ \\
\hline 3 4 million won & $3.051 * * *$ & $4.361 * * *$ & $3.431 * * *$ & $3.412 * * *$ & $4.991 * * *$ & $3.417 * * *$ \\
\hline & $(0.112)$ & $(0.334)$ & $(0.148)$ & $(0.140)$ & $(0.294)$ & $(0.203)$ \\
\hline 4 5 million won & $3.472 * * *$ & $5.640 * * *$ & $3.768 * * *$ & $3.946 * * *$ & $5.968 * * *$ & $3.698 * * *$ \\
\hline & $(0.114)$ & $(0.336)$ & $(0.150)$ & $(0.141)$ & $(0.296)$ & $(0.205)$ \\
\hline $5 \sim 6$ million won & $3.726 * * *$ & $6.442 * * *$ & $3.962 * * *$ & $4.389 * * *$ & $6.876 * * *$ & $4.062 * * *$ \\
\hline & $(0.116)$ & $(0.342)$ & $(0.154)$ & $(0.143)$ & $(0.301)$ & $(0.209)$ \\
\hline 6 7 million won & $3.930 * * *$ & $6.884 * * *$ & $4.181 * * *$ & $4.787 * * *$ & $7.531 * * *$ & $4.320 * * *$ \\
\hline & $(0.120)$ & $(0.357)$ & $(0.161)$ & $(0.148)$ & $(0.311)$ & $(0.217)$ \\
\hline More than & $3.992 * * *$ & $7.528 * * *$ & $4.104 * * *$ & $4.828 * * *$ & $8.165 * * *$ & $4.195 * * *$ \\
\hline million won & $(0.117)$ & $(0.343)$ & $(0.156)$ & $(0.143)$ & $(0.300)$ & $(0.209)$ \\
\hline Father's age & & & & & & \\
\hline $40 \mathrm{~s}$ & $0.276 * * *$ & 0.264 & $0.418 * * *$ & $0.496^{*}$ & 0.089 & $1.024 * *$ \\
\hline & $(0.079)$ & $(0.228)$ & $(0.108)$ & $(0.270)$ & $(0.505)$ & $(0.402)$ \\
\hline $50 \mathrm{~s}$ & 0.087 & -0.087 & $0.274 * *$ & 0.244 & -0.202 & 0.606 \\
\hline & $(0.091)$ & $(0.259)$ & $(0.123)$ & $(0.272)$ & $(0.510)$ & $(0.405)$ \\
\hline Mother's age & & & & & & \\
\hline $40 \mathrm{~s}$ & -0.009 & $0.276^{* *}$ & -0.076 & $0.325 * * *$ & $0.453 * *$ & 0.209 \\
\hline & $(0.040)$ & $(0.117)$ & $(0.055)$ & $(0.098)$ & $(0.190)$ & $(0.143)$ \\
\hline $50 \mathrm{~s}$ & 0.127 & $0.583 * *$ & -0.078 & $0.524 * * *$ & $0.832 * * *$ & $0.284^{*}$ \\
\hline & $(0.085)$ & $(0.242)$ & $(0.114)$ & $(0.114)$ & $(0.221)$ & $(0.165)$ \\
\hline Economic activity & & & & & & \\
\hline Mother only & $-0.919 * * *$ & $-0.938 * * *$ & $-0.962 * * *$ & $-0.860 * * *$ & $-0.818 * * *$ & $-1.180 * * *$ \\
\hline & $(0.079)$ & $(0.218)$ & $(0.104)$ & $(0.091)$ & $(0.179)$ & $(0.130)$ \\
\hline Both & $-0.293 * * *$ & $-0.919 * * *$ & $-0.202 * * *$ & $-0.472 * * *$ & $-0.452 * * *$ & $-0.697 * * *$ \\
\hline & $(0.028)$ & $(0.082)$ & $(0.039)$ & $(0.033)$ & $(0.066)$ & $(0.049)$ \\
\hline None & $-2.379 * * *$ & $-2.736 * * *$ & $-2.476^{* * *}$ & $-1.624 * * *$ & $-1.589 * * *$ & $-2.089 * * *$ \\
\hline & $(0.160)$ & $(0.433)$ & $(0.205)$ & $(0.201)$ & $(0.390)$ & $(0.292)$ \\
\hline Size of region & & & & & & \\
\hline Metropolitan city & $0.368 * *$ & $2.435 * * *$ & $-0.429 * *$ & $-2.008 * * *$ & $1.331 * * *$ & $-5.347 * * *$ \\
\hline & $(0.149)$ & $(0.460)$ & $(0.200)$ & $(0.223)$ & $(0.466)$ & $(0.308)$ \\
\hline Small city & $0.475 * * *$ & $0.618 * * *$ & 0.133 & $-1.279 * * *$ & $0.436 * *$ & $-2.981 * * *$ \\
\hline & $(0.075)$ & $(0.223)$ & $(0.108)$ & $(0.091)$ & $(0.173)$ & $(0.137)$ \\
\hline Rural area & -0.105 & $0.685 * * *$ & $-0.851 * * *$ & $-3.116 * * *$ & $-0.787 * * *$ & $-6.182 * * *$ \\
\hline & $(0.086)$ & $(0.246)$ & $(0.122)$ & $(0.109)$ & $(0.205)$ & $(0.168)$ \\
\hline Year FE & Yes & Yes & Yes & Yes & Yes & Yes \\
\hline Region FE & Yes & Yes & Yes & Yes & Yes & Yes \\
\hline Observations & 70176 & 70176 & 70176 & 107409 & 107409 & 107409 \\
\hline
\end{tabular}

NOTE: * significant at $10 \%, * *$ significant at $5 \%, * * *$ significant at $1 \%$. 
In the case of expenditure on private, one-to-one and group tuition (two more expensive substitutes for hagwon tutoring ${ }^{14}$ ), the coefficients are insignificant for both school types. However, a positive, albeit statistically non-significant coefficient, for high school students seems to suggest that the reduction in spending on hagwon classes might have led to an increase in consumption of other private tutoring activities (i.e., private, one-to-one and group tuition).

The coefficients presented by the father's and mother's education, along with the household income dummies (Table 3) also indicate that yearly spending on private tutoring is significantly and positively correlated to household income and parental education. Indeed, the patterns followed by the socio-economic status variables are similar to those found when the dependent variable is the number of hours spent on private tutoring (Table 2). Households in which the father is a single-income earner spend the most amount of money on private tutoring activities.

\subsection{Discussion}

The DD estimates reported in Tables 2 and 3 indicate that the extension of the hagwon curfew did not significantly reduce the total time and expenditure dedicated to private tutoring as was intended, and that the government intervention was only successful in reducing hagwon tutoring costs. This seems to be in line with the second scenario proposed in subsection 4.1 in which the reduced consumption of hagwon tuition driven by the extension of the curfew is completely or partially replaced by the increase in consumption of other types of private tutoring, including private, one-to-one and group tuition.

\footnotetext{
${ }^{14}$ According to KRIVET (2008a), the mean hourly cost of private tutoring provided by hagwon for middle and high school students was 5,902 won. This figure for one-to-one and group private tutoring was around 16,000 won per month - derived from KRIVET (2008b).
} 
This substitution effect seems to be stronger among high school students. The impact of the regulation on one-to-one and group tuition for middle school students is not very different from zero (Table 3). However, the same estimate for high school students is 0.177 , very similar to the decrease in expenditure on hagwon tutoring, although the value is statistically insignificant.

To obtain a clearer picture of the substitution effect across tuition types, we checked for the existence of heterogeneous effects. Table 4 shows the heterogeneous effects by household income of the extension of the hagwon curfew on time and money spent on private tutoring for high school students.

Table 4. Heterogeneous effects for high school students by household income

\begin{tabular}{lllll}
\hline VARIABLES & Hour & Expenditure & $1: 1 /$ Group & Hagwon \\
\hline Low-income households & -0.107 & -0.077 & $0.347^{*}$ & $-0.255^{*}$ \\
(Less than 4 million won) & $(0.149)$ & $(0.104)$ & $(0.210)$ & $(0.143)$ \\
High-income households & 0.044 & -0.016 & 0.257 & -0.084 \\
(More than 4 million won) & $(0.172)$ & $(0.100)$ & $(0.198)$ & $(0.156)$ \\
\hline
\end{tabular}

NOTE: $*$ significant at $10 \%, * *$ significant at $5 \%, * * *$ significant at $1 \%$.

In the table, the whole sample of high school students is divided into two groups ${ }^{15}$ : lowincome households and high-income household. Neither group of high school students reduces the total number of hours or expenditure dedicated to private tuition. We can conjecture that these effects are not heterogeneous across different income groups. However, if we examine the way in which the enforcement of the hagwon curfew has influenced private, one-to-one and group tuition and hagwon tutoring, we see that the two groups reacted quite differently to the intervention. The first row in Table 4 shows that high school students from

\footnotetext{
${ }^{15}$ In the SPEE dataset, information on actual household income is not provided. Parents self-reported to which of the eight monthly household income groups (see table A1) their household belonged to. The sample was divided into two groups - low-income and high-income households-. According to the Household Income and Expenditure Survey conducted by Korean National Statistics Office, average monthly household income was 4,076,876 Korean won in 2012. We therefore took the 4 million Korean won as the threshold between both groups.
} 
low-income households significantly increased their consumption of private, one-to-one and group tuition when they had to reduce significantly their consumption of hagwon tutoring. This is clear evidence that the substitution from private hagwon tutoring to private, one-toone and group tuition was more intense among lower income high school students. Conversely, high school students from high-income families did not seem to be as greatly affected by the intervention (given that all of the coefficients are insignificant despite showing the same signs as for the other group).

How can we explain the heterogeneous reactions of the two types of household to the policy and what are the consequences of these heterogeneous effects? Our results show that the demand of high school students for private tutoring is inelastic, given that they are likely to regard private tutoring services as indispensable for excelling on the CSAT, the critical point in their academic lives. Thus, when their consumption of hagwon tutoring was regulated by the policy intervention, a considerable number of high school students appear to have opted to increase their use of private, one-to-one and group tuition to offset the reduction in hagwon classes. More specifically, this substitution across types of tuition is driven mainly by high school students from low-income families, those traditionally more reliant on the private classes offered by hagwon (see Appendix A4). In contrast, high school students from high-income families have, in addition to being consumers of hagwon tutoring, been active buyers of other types of private tuition. In other words, given that their consumption of private tutoring services had already shown an inclination for one-to-one and group tuition, regulations on the supply of hagwon did not affect their choice as much.

Finally, we checked the robustness of these results by performing a placebo test. In this test, we simulated the enforcement of the hagwon curfew as if it had been introduced between 2009 and 2010, that is, one year before actual enforcement. This analysis was replicated both for the whole sample of high school students and for the high-income and low-income 
households separately. Results are reported in Table 5 and, as expected, no significant effects were found.

Table 5. Results of a placebo enforcement of the curfew for high school students.

\begin{tabular}{lllll}
\hline VARIABLES & Hour & Expenditure & $1: 1 /$ Group & Hagwon \\
\hline All & -0.017 & -0.113 & -0.069 & -0.159 \\
& $(0.115)$ & $(0.073)$ & $(0.146)$ & $(0.109)$ \\
Low-income households & -0.005 & -0.059 & 0.001 & -0.201 \\
(Less than 4 million won) & $(0.167)$ & $(0.114)$ & $(0.234)$ & $(0.160)$ \\
High-income households & -0.056 & -0.127 & -0.039 & -0.131 \\
(More than 4 million won) & $(0.201)$ & $(0.113)$ & $(0.231)$ & $(0.183)$ \\
\hline
\end{tabular}

NOTE: * significant at $10 \%, * *$ significant at $5 \%, * * *$ significant at $1 \%$.

The imposition of the strengthened hagwon curfew has been more successful in changing private tutoring consumption patterns than in reducing the total time dedicated to private tutoring and the resources spent on these activities. This raises issues of both efficiency and equity. In the case of efficiency, while families managed to reduce their consumption of hagwon - a foreseeable outcome, given the nature of the regulations, their children increased the amount of time - and money - spent on other, more expensive, types of private tuition. The policy failed therefore to achieve its main objective - reducing the consumption of private tutoring - due to the inelastic demand of such tutoring, closely linked to the overheated competition for admission to the most prestigious universities. The impact of the enforcement of the curfew on efficiency therefore depends on the effectiveness of each private tuition type for transmitting skills and, ultimately, the impact of these skills on economic growth. While examining this question is beyond the scope of this paper, it should be highlighted that if there are differences in quality between types of private tuition, the change in consumption patterns may have an impact on efficiency. Additionally, the impact of the enforcement of the curfew on efficiency is closely linked to its distributional effects. 
Hence, an increase in the consumption of more expensive private tuition by low- income families may raise the overall performance of these students - that is, if the assumption of "superior quality" holds. Moreover, marginal gains in academic performance may prove to be crucial in an ultra-competitive environment. However, the substitution process generated by the extension of the curfew also has its losers, namely, the low-income families that paid for hagwon tutoring but who cannot afford other types of tuition. Therefore, as previous studies suggest that receiving private tuition has a positive impact on academic performance, the regulation has a negative impact on the equality of educational opportunities among this last subgroup of students. The analysis of the impact on academic performance of different types of private tutoring is thus a promising field for further research.

To conclude, the Korean experience should serve to provide relevant guidelines for policymakers in countries with large private tutoring markets. The first lesson is straightforward: regulating - and effectively controlling - the operating hours of educational institutions has an impact on the consumption of the services provided by those institutions. However, the aggregate effect of these measures on the consumption of private tutoring is difficult to predict, as it seems to depend on the elasticity of demand of educational services, the existence of substitute services, and the profile of the consumers of the different types of private tuition. Imposing a strengthened curfew on the academies in Korea had a neutral effect on the overall consumption of private tutoring because of the inelastic demand for these activities and the existence of substitute services. Moreover, the Korean authorities learned decades ago that efforts to ban or regulate one-to-one tuition lead to an increase in black market activities. Therefore, policymakers who seek to cool the demand for private tutoring should perhaps focus their attention on tackling the underlying causes of the overheated demand for education, since the proliferation of private tutoring is usually the symptom of more complex issues. The overheated demand for private tutoring is generated, 
among other causes ${ }^{16}$, by the combination of a widespread acceptance of education as the main social promotion mechanism, and the relatively scarce supply of high quality higher education institutions. While changing social perceptions would be a difficult long-term task, public authorities may help relaxing the demand for private tutoring through supply policies. Increasing the number of students admitted in high-quality public institutions and enhancing the quality of vocational studies are among the policies which could be explored.

${ }^{16}$ Kim and Park (2010) provide a literature review on this issue. 


\section{References}

Angrist, J. D., Pischke, J-S. 2009. Mostly harmless econometrics: An empiricist's companion. Princeton: Princeton University Press.

Bae, J. 2009. "Will hagwon curfew work?". The Korea Times. 26th April. Retrieved November 12, 2015 (http://koreatimes.co.kr/www/news/nation/2009/04/113_43860.html).

Bertrand, M., Duflo, E., Mullainathan, S. 2004. "How much should we trust differences-indifferences estimates?" Quarterly Journal of Economics, 119(1), 249-275. DOI: $10.1162 / 003355304772839588$

Bourdieu, P. 1973. Cultural reproduction and social reproduction. In Knowledge, education, and cultural change: Papers in the sociology of education, ed. Richard Brown. London: Tavistock.

Bray, M. 1999. The shadow education system: Private tutoring and its implications for planners. Paris: UNESCO.

Bray, M. 2006. "Private supplementary tutoring: Comparative perspectives on patterns and implications". Compare: A Journal of Comparative and International Education, 36(4), 515-530. DOI: 10.1080/03057920601024974

Bray, M. 2009. Confronting the Shadow Education System: What Government Policies for What Private Tutoring? Paris: UNESCO International Institute for Educational Planning (IIEP).

Bray, M. 2013. "Shadow Education: Comparative Perspectives on the Expansion and Implications of Private Supplementary Tutoring." Procedia - Social and Behavioral Sciences, 77, 412-420.

Bray, M., Kobakhidze, M. N. 2014. "Measurement issues in research on shadow education: Challenges and pitfalls encountered in TIMSS and PISA". Comparative Education Review, 
58(4), 590-620. DOI: 10.1086/677907

Bray, M., Kwo, O. W. Y. 2014. Regulating Private Tutoring for Public Good: Policy Options for Supplementary Education in Asia. Bangkok and Hong Kong: UNESCO and Comparative Education Research Centre, The University of Hong Kong.

Bray, M., Kwok, P. 2003. "Demand for private supplementary tutoring: Conceptual considerations, and socio-economic patterns in Hong Kong”. Economics of Education Review, 22, 611-620. DOI: 10.1016/S0272-7757(03)00032-3

Byun, S. 2010. "Does policy matter in shadow education spending? Revisiting the effects of the high school equalization policy in South Korea”. Asia Pacific Education Review, 11 (1), 83-96.

Byun, S-Y, Schofer, E., Kim, K-K. 2012. "Revisiting the role of cultural capital in East Asian educational systems: The case of South Korea”. Sociology of Education, 85(3), 219-239.

Chae, S., Hong, J., Lee, T. 2005. Anatomy of the rank structure of Korean universities: Towards a design of integrated policies for education reform in Korea. Seoul: AP EPRI/KEDI publications.

Kang, C., Park, C., Lee, M-J. 2007. "Effects of ability mixing in high school on adulthood earnings: quasiexperimental evidence from South Korea”. Journal of Population Economics, 20, 269-297.

Choi, Á. 2010. "Analysis of private tutoring decisions in Korea: A game theory approach". Regional and Sectoral Economic Studies, 10(2), 23-36.

Choi, Á., Calero, J., Escardíbul, J-O. 2012. "Private tutoring and academic achievement in Korea: An approach through PISA-2006”. KEDI Journal of Educational Policy, 9(2), 299322.

Choi, H. 2008. "The effect of private tutoring on college entrance". International Economic Journal, 14(1). 73-110. 
Choi, J., Cho, R. N. 2015. "Evaluating the effects of governmental regulations on South Korean private cram schools". Asia Pacific Journal of Education. DOI: $10.1080 / 02188791.2015 .1064356$

Chung, B. 2002. "Korea's War on Private Tutoring". Paper presented at the Second International Forum on Education Reform, Bangkok, September 2-5.

Dang, H. 2007. "The determinants and impact of private tutoring classes in Vietnam". Economics of Education Review, 26, 684-699.

Dang, H., Rogers, H. 2008. "How to interpret the growing phenomenon of private tutoring: Human capital deepening, inequality increasing, or waste of resources?" World Bank Policy Research Working Paper, 4530, World Bank, Washington, DC.

Han, S. 2011. "Private education costs fall for 1st time in decade". The Korea Times. $\begin{array}{llll}15^{\text {th }} \text { February. } & \text { Retrieved } & \text { November } & 12,\end{array}$ (http://koreatimes.co.kr/www/news/nation/2011/02/113_81456.html).

Kang, C. 2007. "Does money matter? The effect of private educational expenditures on academic performance". Working Paper, 704, Department of Economics, National University of Singapore.

Kang, S. 2010. "Hagwon curfew backsliding". The Korea Times. 1st April. Retrieved November

12 2015

(http://www.koreatimes.co.kr/www/news/nation/2010/04/113_63489.html).

KEDI. 2009. Facts and figures on an analysis of educational statistics. Seoul: Korean Educational Development Institute. (In Korean).

KEDI. 2012. Results and issues of hagwon management policies. Seoul: Korean Educational Development Institute. (In Korean).

Kim, H. 2010. "Analysis of the effects of private education on academic achievement and labor market performance". KDI Reports, 2010-05. (In Korean). 
Kim, J. 2007. "Shadow education around the world: Its cause and the effects". Public Economics, 12(2), 119-151. (In Korean).

Kim, J. 2009. "The effectiveness of regulation for cram schools on demand for private tutoring”. The Journal of Educational Administration, 27(4), 465-487. (In Korean).

Kim, J-H, Chang, J. 2010. "Do governmental regulations for cram schools decrease the number of hours students spend on private tutoring?" KEDI Journal of Educational Development, 7 (1), 3-21.

Kim, J-H., Park, D. 2010. "The determinants of demand for private tutoring in South Korea". Asia Pacific Education Review, 11, 411-421.

Kim, S., and Lee, J. 2010. "Private tutoring and demand for education in South Korea". Economic Development and Cultural Change, 58(2), 259-296. DOI: 10.1086/648186

Kim,T. 2004. "Shadow education: school quality and demand for private tutoring in Korea". KDI School of Pub Policy \& Management Paper No. 04-21.

Korean Economic Daily. 2015. “No. of Private Learning Centers Breaks 100,000 Level for First Time". Korean Economic Daily. 19th March. Retrieved November 12, 2015 (http://english.hankyung.com/news/apps/news.view?c1=04\&nkey=201503191203111).

KOSTAT. 2011. The Survey of Private Education Expenditures. Seoul: Korea Statistics.

KOSTAT. 2012. Household Income and Expenditure Survey. Seoul: Korea Statistics.

KRIVET. 2008a. A survey study on private tutoring providers 2: survey on hagwon. Seoul: Ministry of Education, Science, and Technology.

KRIVET. 2008b. A survey study on private tutoring providers 5: survey on private lesson. Seoul: Ministry of Education, Science, and Technology.

Lee, S., Brinton, M.C. 1996. "Elite education and social capital: The case of South Korea". Sociology of Education, 69(3), 177-192. DOI: 10.2307/2112728

Lee, B., Jwa, H., Lim, S. 2014. "The effects of private tutoring and parenting behaviors on 
children's academic achievement in Korea: Are there differences between low- and highincome groups?". KEDI Journal of Educational Policy, 11(2), 163-178.

Lee, C.J., Lee, H., Jang, H-M. 2010. The history of policy responses to shadow education ain South Korea: Implications for the next cycle of policy responses. Asia Pacific Education Review, 11 (1), 97-108.

OECD. 2011. Education at a Glance 2011: highlights. Paris: OECD.

OECD. 2012a. Economic surveys: Korea 2012. Paris: OECD.

OECD. 2012b. Korea-country note- Education at a glance: OECD indicators 2012. Paris: OECD.

OECD. 2014. Strong performers and successful reformers in education: Lessons from PISA for Korea. Paris: OECD.

OECD. 2015. Education at a Glance 2015. Paris: OECD.

Park, H, Byun S-Y, Kim, K-K. 2011. "Parental involvement and students' cognitive outcomes in Korea: Focusing on private tutoring”. Sociology of Education, 84(1), 3-22.

Rhie, S., Lee, S., Chae, K. 2011. "Sleep patterns and school performance of Korean adolescents assessed using a Korean version of the pediatric daytime sleepiness scale". Korean Journal of Pediatrics, 54(1), 29-35. DOI: 10.3345/kjp.2011.54.1.29

Slaughter, M. J. 2001. Trade liberalization and per capita income convergence: A differencein-differences analysis. Journal of International Economics, 55: 203-228.

Tansel, A., Bircan F. 2006. "Demand for education in Turkey: A tobit analysis of private tutoring expenditures". Economics of Education Review, 25, 303-313. DOI: 10.1016/j.econedurev.2005.02.003 
Appendix A1. Definition of main variables

\begin{tabular}{|c|c|}
\hline Variables & Definition \\
\hline Hour & Weekly hours spent on private tutoring for academic purpose \\
\hline Expenditure & Yearly spending on private tutoring for academic purpose \\
\hline One-to-one tutoring & Yearly spending on 'one-to-one tutoring' \\
\hline Group tutoring & Yearly spending on 'group tutoring' \\
\hline Hagwon tutoring & Yearly spending on 'taking lessons at hagwon' \\
\hline Workbook tutoring & Yearly spending on 'textbooks with tutor's visit' type tutoring \\
\hline Internet tutoring & Yearly spending on 'paid internet and correspondence lectures' type \\
\hline Female & 1 if female; 0 otherwise \\
\hline Father's education & (The reference group is middle school degree of less) \\
\hline High school & 1 if father has a high school degree; 0 otherwise \\
\hline University & 1 if father has a university degree; 0 otherwise \\
\hline Graduate school & 1 if father has a graduate degree or more; 0 otherwise \\
\hline Mother's education & (The reference group is middle school degree or less) \\
\hline High school & 1 if mother has a high school degree; 0 otherwise \\
\hline University & 1 if mother has a university degree; 0 otherwise \\
\hline Graduate school & 1 if mother has a graduate degree or more; 0 otherwise \\
\hline Household income & (The reference group is less than 1 million won) \\
\hline 1 2 million won & 1 if monthly household income is between $1 \sim 2$ million won; 0 \\
\hline 2 3 million won & 1 if monthly household income is between $2 \sim 3$ million won; 0 \\
\hline 3 4 million won & 1 if monthly household income is between $3 \sim 4$ million won; 0 \\
\hline 4 5 million won & 1 if monthly household income is between $4 \sim 5$ million won; 0 \\
\hline 5 6 million won & 1 if monthly household income is between $5 \sim 6$ million won; 0 \\
\hline 6 7 million won & 1 if monthly household income is between $6 \sim 7$ million won; 0 \\
\hline More than 7 million won & 1 if monthly household income is more than 7 million won; 0 \\
\hline Father's age & (The reference group is father in his twenties or thirties) \\
\hline $40 \mathrm{~s}$ & 1 if father is in his forties; 0 otherwise \\
\hline $50 \mathrm{~s}$ & 1 if father is in his fifties; 0 otherwise \\
\hline Mother's age & (The reference group is mother in her twenties or thirties) \\
\hline $40 \mathrm{~s}$ & 1 if mother is in her forties; 0 otherwise \\
\hline $50 \mathrm{~s}$ & 1 if mother is in her fifties; 0 otherwise \\
\hline Economic activity & (The reference group is only father works) \\
\hline Mother only & 1 if only mother works; 0 otherwise \\
\hline Both & 1 if both father and mother work; 0 otherwise \\
\hline None & 1 if neither father nor mother works; 0 otherwise \\
\hline Academic performance & (The reference group is top $10 \%$ of the class) \\
\hline $10 \sim 30 \%$ & 1 if student is between $10 \sim 30 \%$ of the class; 0 otherwise \\
\hline $30 \sim 60 \%$ & 1 if student is between $30 \sim 60 \%$ of the class; 0 otherwise \\
\hline $60 \sim 80 \%$ & 1 if student is between $60 \sim 80 \%$ of the class; 0 otherwise \\
\hline Bottom $20 \%$ & 1 if student is below bottom $20 \%$ of the class; 0 otherwise \\
\hline Size of the region & (The reference group is Seoul) \\
\hline Metropolitan city & 1 if metropolitan city; 0 otherwise \\
\hline Small city & 1 if small city; 0 otherwise \\
\hline Rural area & 1 if rural area; 0 otherwise \\
\hline Regulation & 1 if the strengthened curfew is implemented; 0 otherwise \\
\hline
\end{tabular}


Appendix A2. Descriptives of main variables

\begin{tabular}{|c|c|c|c|c|c|}
\hline \multirow[b]{2}{*}{ Variables } & \multicolumn{5}{|c|}{ Mean } \\
\hline & $\begin{array}{c}\text { All } \\
\text { Students }\end{array}$ & $\begin{array}{c}\text { Middle } \\
\text { School } \\
\text { Students }\end{array}$ & $\begin{array}{c}\text { High } \\
\text { school } \\
\text { students }\end{array}$ & $\begin{array}{c}\text { No } \\
\text { Tutoring } \\
(\text { Hour }=0)\end{array}$ & $\begin{array}{c}\text { Positive } \\
\text { Tutoring } \\
(\text { Hour }>0) \\
\end{array}$ \\
\hline Hour & 4.991 & 6.924 & 3.707 & 0 & 8.495 \\
\hline Expenditure & 278.110 & 296.578 & 265.835 & 0 & 473.340 \\
\hline One-to-one tutoring & 68.004 & 46.752 & 82.129 & 0 & 115.742 \\
\hline Group tutoring & 32.118 & 30.488 & 33.201 & 0 & 54.665 \\
\hline Hagwon tutoring & 168.35 & 207.095 & 142.656 & 0 & 286.590 \\
\hline Workbook tutoring & 3.794 & 8.083 & 0.943 & 0 & 6.458 \\
\hline Internet tutoring & 5.808 & 4.159 & 6.904 & 0 & 9.885 \\
\hline Female & 0.477 & 0.472 & 0.481 & 0.462 & 0.488 \\
\hline \multicolumn{6}{|l|}{ Father's education } \\
\hline Middle school or less & 0.051 & 0.049 & 0.051 & 0.086 & 0.026 \\
\hline High school & 0.432 & 0.441 & 0.426 & 0.517 & 0.372 \\
\hline University & 0.441 & 0.441 & 0.441 & 0.350 & 0.507 \\
\hline Graduate school & 0.076 & 0.069 & 0.081 & 0.047 & 0.095 \\
\hline \multicolumn{6}{|l|}{ Mother's education } \\
\hline Middle school or less & 0.054 & 0.050 & 0.058 & 0.087 & 0.032 \\
\hline High school & 0.575 & 0.569 & 0.578 & 0.643 & 0.528 \\
\hline University & 0.342 & 0.355 & 0.334 & 0.253 & 0.403 \\
\hline Graduate school & 0.029 & 0.026 & 0.030 & 0.017 & 0.037 \\
\hline \multicolumn{6}{|l|}{ Household income } \\
\hline Less than 1 million won & 0.049 & 0.058 & 0.043 & 0.089 & 0.022 \\
\hline $1 \sim 2$ million won & 0.138 & 0.143 & 0.134 & 0.211 & 0.086 \\
\hline $2 \sim 3$ million won & 0.204 & 0.205 & 0.204 & 0.242 & 0.178 \\
\hline $3 \sim 4$ million won & 0.214 & 0.213 & 0.215 & 0.196 & 0.226 \\
\hline $4 \sim 5$ million won & 0.156 & 0.153 & 0.159 & 0.119 & 0.182 \\
\hline 5 6 million won & 0.098 & 0.094 & 0.100 & 0.064 & 0.122 \\
\hline $6 \sim 7$ million won & 0.050 & 0.049 & 0.050 & 0.028 & 0.065 \\
\hline More than 7 million won & 0.091 & 0.085 & 0.095 & 0.051 & 0.119 \\
\hline \multicolumn{6}{|c|}{ Economic activity participation } \\
\hline Father only & 0.359 & 0.372 & 0.351 & 0.328 & 0.381 \\
\hline Mother only & 0.085 & 0.087 & 0.083 & 0.123 & 0.058 \\
\hline Both & 0.538 & 0.518 & 0.552 & 0.519 & 0.552 \\
\hline None & 0.018 & 0.023 & 0.014 & 0.030 & 0.009 \\
\hline \multicolumn{6}{|l|}{ Academic performance } \\
\hline Top $10 \%$ & 0.109 & 0.116 & 0.102 & 0.067 & 0.137 \\
\hline $10 \sim 30 \%$ & 0.208 & 0.215 & 0.204 & 0.148 & 0.250 \\
\hline $30 \sim 60 \%$ & 0.332 & 0.309 & 0.347 & 0.308 & 0.349 \\
\hline $60 \sim 80 \%$ & 0.216 & 0.210 & 0.221 & 0.266 & 0.182 \\
\hline Bottom $20 \%$ & 0.135 & 0.150 & 0.126 & 0.211 & 0.082 \\
\hline Number of observations & 190,276 & 75,973 & 114,303 & 78,480 & 111,796 \\
\hline
\end{tabular}

NOTE: All the variables regarding private tutoring expenditure are annual spending presented in 10 thousands of Korean won 
Appendix A3. Number of observations by region, year, and school level

\begin{tabular}{|c|c|c|c|c|c|c|}
\hline & \multirow[b]{2}{*}{ Region } & \multicolumn{4}{|c|}{ Middle school students (p.m.) } & \multirow[b]{2}{*}{ Total } \\
\hline & & 2009 & 2010 & 2011 & 2012 & \\
\hline \multirow{5}{*}{ Treatment group } & Daegu & 1,343 & 1,348 & 1,276 & 1,226 & 5,193 \\
\hline & Jeonnam & 878 & 905 & 910 & 999 & 3,692 \\
\hline & Incheon & 1,904 & 1,882 & 1,810 & 1,722 & 7,318 \\
\hline & Gyeonggi & 3,916 & 3,850 & 3,818 & 3,697 & 15,281 \\
\hline & Jeju & 687 & 701 & 833 & 861 & 3,082 \\
\hline \multirow{10}{*}{ Control group } & Seoul & 3,291 & 3,243 & 3,196 & 3,013 & 12,743 \\
\hline & Busan & 1,588 & 1,576 & 1,554 & 1,555 & 6,273 \\
\hline & Gwangju & 1,527 & 1,481 & 1,424 & 1,503 & 5,935 \\
\hline & Chungbuk & 866 & 847 & 861 & 746 & 3,320 \\
\hline & Gyeongbuk & 828 & 837 & 810 & 799 & 3,274 \\
\hline & Ulsan & 906 & 896 & 862 & 777 & 3,441 \\
\hline & Gyeongnam & 1,606 & 1,601 & 1,588 & 1,626 & 6,421 \\
\hline & Total & 19,340 & 19,167 & 18,942 & 18,524 & 75,973 \\
\hline & \multicolumn{6}{|c|}{ High school students (p.m.) } \\
\hline & Region & 2009 & 2010 & 2011 & 2012 & Total \\
\hline \multirow{4}{*}{ Treatment group } & Daegu & 2,273 & 2,263 & 2,218 & 2,302 & 9,056 \\
\hline & Gwangju & 2,261 & 2,301 & 2,228 & 2,246 & 9,036 \\
\hline & Gyeonggi & 4,367 & 4,303 & 4,260 & 4,037 & 16,967 \\
\hline & Incheon & 1,620 & 1,666 & 1,581 & 1,498 & 6,365 \\
\hline \multirow{9}{*}{ Control group } & Seoul & 4,570 & 4,619 & 4,806 & 4,447 & 18,442 \\
\hline & Busan & 2,244 & 2,207 & 2,351 & 2,164 & 8,966 \\
\hline & Ulsan & 1,464 & 1,431 & 1,408 & 1,225 & 5,528 \\
\hline & Chungbuk & 1,642 & 1,656 & 2,119 & 2,009 & 7,426 \\
\hline & Jeonnam & 1,969 & 1,980 & 2,016 & 1,858 & 7,823 \\
\hline & Gyeongbuk & 2,453 & 2,434 & 2,634 & 2,367 & 9,888 \\
\hline & Gyeongnam & 2,576 & 2,508 & 2,546 & 2,405 & 10,035 \\
\hline & Jeju & 1,073 & 1,082 & 1,315 & 1,301 & 4,771 \\
\hline & Total & 28,512 & 28,450 & 29,482 & 27,859 & 114,303 \\
\hline
\end{tabular}


Appendix A4. Distribution of expenditures for different forms of private tutoring by household income

\begin{tabular}{|c|c|c|c|c|c|c|}
\hline \multirow[b]{2}{*}{ Household income } & \multicolumn{6}{|c|}{ Middle school students } \\
\hline & One-to-one & Group & Hagwon & Workbook & Internet & Total \\
\hline Less than 1 million won & $\begin{array}{l}6.600 \\
(9 \%)\end{array}$ & $\begin{array}{r}5.844 \\
(8 \%)\end{array}$ & $\begin{array}{r}57.976 \\
(76 \%)\end{array}$ & $\begin{array}{r}4.045 \\
(5 \%)\end{array}$ & $\begin{array}{r}1.422 \\
(2 \%)\end{array}$ & 75.887 \\
\hline 1 2 million won & $\begin{array}{r}11.730 \\
(9 \%)\end{array}$ & $\begin{array}{r}10.559 \\
(8 \%)\end{array}$ & $\begin{array}{r}104.474 \\
(78 \%)\end{array}$ & $\begin{array}{r}5.835 \\
(4 \%)\end{array}$ & $\begin{array}{r}1.821 \\
(1 \%)\end{array}$ & 134.419 \\
\hline $2 \sim 3$ million won & $\begin{array}{r}22.005 \\
(10 \%)\end{array}$ & $\begin{array}{r}20.692 \\
(10 \%)\end{array}$ & $\begin{array}{r}162.117 \\
(75 \%)\end{array}$ & $\begin{array}{r}8.201 \\
(4 \%)\end{array}$ & $\begin{array}{r}3.145 \\
(1 \%)\end{array}$ & 216.161 \\
\hline $3 \sim 4$ million won & $\begin{array}{r}37.008 \\
(12 \%)\end{array}$ & $\begin{array}{r}30.100 \\
(10 \%)\end{array}$ & $\begin{array}{r}216.726 \\
(73 \%)\end{array}$ & $\begin{array}{r}8.969 \\
(3 \%)\end{array}$ & $\begin{array}{r}4.482 \\
(2 \%)\end{array}$ & 297.286 \\
\hline $4 \sim 5$ million won & $\begin{array}{r}58.761 \\
(16 \%)\end{array}$ & $\begin{array}{r}39.809 \\
(11 \%)\end{array}$ & $\begin{array}{r}255.031 \\
(69 \%)\end{array}$ & $\begin{array}{r}9.047 \\
(2 \%)\end{array}$ & $\begin{array}{r}5.512 \\
(1 \%)\end{array}$ & 368.160 \\
\hline 5 6 million won & $\begin{array}{r}78.803 \\
(18 \%)\end{array}$ & $\begin{array}{r}47.842 \\
(11 \%)\end{array}$ & $\begin{array}{r}286.087 \\
(67 \%)\end{array}$ & $\begin{array}{r}8.596 \\
(2 \%)\end{array}$ & $\begin{array}{r}6.103 \\
(1 \%)\end{array}$ & 427.430 \\
\hline $6 \sim 7$ million won & $\begin{array}{r}95.495 \\
(20 \%)\end{array}$ & $\begin{array}{r}51.604 \\
(11 \%)\end{array}$ & $\begin{array}{r}315.634 \\
(66 \%)\end{array}$ & $\begin{array}{r}9.586 \\
(2 \%)\end{array}$ & $\begin{array}{r}6.830 \\
(1 \%)\end{array}$ & 479.150 \\
\hline \multirow[t]{2}{*}{ More than 7 million won } & $\begin{array}{r}132.854 \\
(25 \%) \\
\end{array}$ & $\begin{array}{r}57.628 \\
(11 \%) \\
\end{array}$ & $\begin{array}{r}331.414 \\
(62 \%) \\
\end{array}$ & $\begin{array}{r}8.983 \\
(2 \%) \\
\end{array}$ & $\begin{array}{r}5.503 \\
(1 \%) \\
\end{array}$ & 536.383 \\
\hline & \multicolumn{6}{|c|}{ High school students } \\
\hline Household income & One-to-one & Group & Hagwon & workbook & Internet & Total \\
\hline Less than 1 million won & $\begin{array}{l}11.617 \\
(18 \%)\end{array}$ & $\begin{array}{r}5.870 \\
(9 \%)\end{array}$ & $\begin{array}{r}42.326 \\
(67 \%)\end{array}$ & $\begin{array}{r}0.714 \\
(1 \%)\end{array}$ & $\begin{array}{r}2.899 \\
(5 \%)\end{array}$ & 63.427 \\
\hline $1 \sim 2$ million won & $\begin{array}{r}22.170 \\
(21 \%)\end{array}$ & $\begin{array}{r}12.267 \\
(12 \%)\end{array}$ & $\begin{array}{r}65.156 \\
(63 \%)\end{array}$ & $\begin{array}{r}0.752 \\
(1 \%)\end{array}$ & $\begin{array}{r}3.551 \\
(3 \%)\end{array}$ & 103.896 \\
\hline $2 \sim 3$ million won & $\begin{array}{r}39.132 \\
(24 \%)\end{array}$ & $\begin{array}{r}20.788 \\
(13 \%)\end{array}$ & $\begin{array}{r}99.899 \\
(60 \%)\end{array}$ & $\begin{array}{r}0.924 \\
(1 \%)\end{array}$ & $\begin{array}{l}5.393 \\
(3 \%)\end{array}$ & 166.137 \\
\hline $3 \sim 4$ million won & $\begin{array}{r}65.737 \\
(27 \%)\end{array}$ & $\begin{array}{r}31.971 \\
(13 \%)\end{array}$ & $\begin{array}{r}136.760 \\
(56 \%)\end{array}$ & $\begin{array}{r}1.171 \\
(0 \%)\end{array}$ & $\begin{array}{r}6.527 \\
(3 \%)\end{array}$ & 242.167 \\
\hline $4 \sim 5$ million won & $\begin{array}{r}94.538 \\
(30 \%)\end{array}$ & $\begin{array}{r}40.562 \\
(13 \%)\end{array}$ & $\begin{array}{r}165.750 \\
(53 \%)\end{array}$ & $\begin{array}{r}0.866 \\
(0 \%)\end{array}$ & $\begin{array}{r}8.553 \\
(3 \%)\end{array}$ & 310.269 \\
\hline $5 \sim 6$ million won & $\begin{array}{r}125.854 \\
(33 \%)\end{array}$ & $\begin{array}{r}48.919 \\
(13 \%)\end{array}$ & $\begin{array}{r}202.205 \\
(52 \%)\end{array}$ & $\begin{array}{r}0.917 \\
(0 \%)\end{array}$ & $\begin{array}{r}9.273 \\
(2 \%)\end{array}$ & 387.167 \\
\hline 6 7 million won & $\begin{array}{r}156.437 \\
(35 \%)\end{array}$ & $\begin{array}{r}58.354 \\
(13 \%)\end{array}$ & $\begin{array}{r}227.702 \\
(50 \%)\end{array}$ & $\begin{array}{r}0.828 \\
(0 \%)\end{array}$ & $\begin{array}{r}9.184 \\
(2 \%)\end{array}$ & 452.505 \\
\hline More than 7 million won & $\begin{array}{r}222.274 \\
(40 \%) \\
\end{array}$ & $\begin{array}{r}62.478 \\
(11 \%) \\
\end{array}$ & $\begin{array}{r}256.622 \\
(46 \%) \\
\end{array}$ & $\begin{array}{r}1.063 \\
(0 \%) \\
\end{array}$ & $\begin{array}{r}11.102 \\
(2 \%) \\
\end{array}$ & 553.540 \\
\hline
\end{tabular}

NOTE: all the expenditures are annual spending presented in 10 thousands of Korean won. The percentages of students using each type of private tutoring per income group are in parentheses. 